The mechanism responsible for the protective action of phosphates on penicillin is not clear at present, but it may well be effected through an esterification of part of the molecule similar to that reported for a number of other compounds of biological interest", and a consequent blocking of an enzyme system involved in the processes of destruction.

Research Division,

Robertson Pratt

Cutter Laboratories,

Berkeley,

California.

Dec. 26.

1 Pratt, R., Amer, J. Bot., 32, 528 (1945).

'Pulvertaft, R. J. U., and Yudkin, J., Nature, 156, 82 (1945), - Goyan, F. M., Enright, J. M., and Wells, J. M., J. Amer. Pharm.
A8soc. (Sci. Ed.), 33, 74 (1944).

‘ Kumler, W. D., and Eiler, J. J., J. Amer. Chem. Soc., 65, 2355 (1943).

\section{New Substances Exerting a Combined Bac- teriostatic and Respiration-inhibiting Effect on Tubercle Bacilli}

Most of the preparations with a chemotherapeutic effect against tubercle bacilli which have hitherto been tested have been bacteriostatic. The reactions occurring between chemotherapeutic substances of this type and the bacterial cell are of a reversible character. A considerably better effect should be achieved if a preparation producing irreversible changes could be discovered. The simple sulphanilamides, that is, those.the effect of which is counteracted by para-aminobenzoic acid, are typical of such bacteriostatic substances. They give a good effect in vitro, and in animal experiments they show a definite though weak effect ${ }^{1}$. Derivatives of the simple sulphanilamides, for example, promin, have given better results in in vivo experiments ${ }^{2}$.

It seems probable that the value of the sulphanilamides as chemotherapeutic agents would be greatly increased if, in some way, they could be made to interfere with bacterial metabolism directly. Simple sulphanilamides and promin certainly can interfere in bacterial metabolism. Thus measurements of the respiration of pathogenic human tubercle bacilli'in a Warburg respirometer show a reduction in oxygen consumption under the influence of sulphsnilamide, sulphathiazole, sulphanilylmethylpyrimidin, promin and other substances ${ }^{3}$. This effect can, however, only be detected when very high concentrations, for example, $0 \cdot 2-1 \cdot 0$ per cent of the substances are used.

In ordinary therapeutic concentrations, the sulphadrags have no action in inhibiting respiration even if the cultures have been treated with them for several days or weeks previous to the test with the respirometer. It is possible that the desired effect might be achieved if bacteriostatic substances were coupled with substances inhibiting respiration. These experiments have therefore been aimed at finding out whether chemical combination of two such substances would give a compound which retained its capacity for interference in bacterial metabolism. It is possible in some cases to produce compounds having such an effect, as has been shown by Dr. H. Willstaedt, Wenner-Gren's Institute, Stockholm, who very kindly placed them at my disposal ${ }^{4,5}$.

The effect of such compounds in inhibiting the growth of tubercle bacilli on Löwenstein's medium was studied, as well as their effect on respiration, in order to find out whether they would show the same or better bacteriostatic effect than that of the com. ponents. It had been shown that with a mixture of the components the effect was merely additive.

In the accompanying table are given the results of tests on [2-methyl-indole-(3-azo-4)-benzene-1sulphonyl]-3,4-dimethylbenzamide $(W .134)^{\circ}$, and its components $p$-amino-benzenesulphonyl-3,4-dimethyl. benzamide('Irgafen') and 2-methylindole (M.1). Their effect was tested on pathogenic human bacilli.

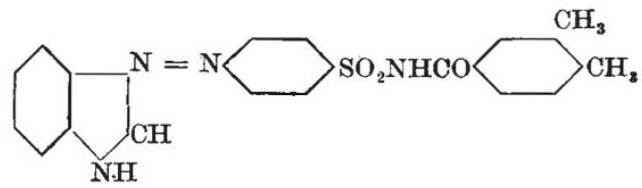

W. 134
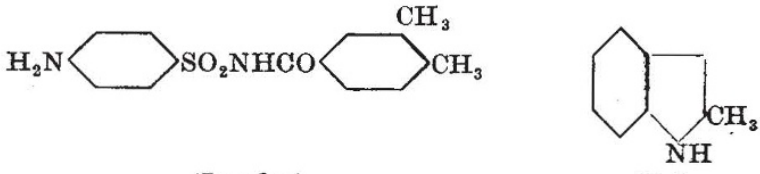

'Irgafen'

M. I

\begin{tabular}{|c|c|c|c|c|c|c|c|}
\hline \multirow[t]{2}{*}{$\begin{array}{l}\text { Sub- } \\
\text { stance }\end{array}$} & \multirow[t]{2}{*}{$\begin{array}{l}\text { Elementary } \\
\text { formula }\end{array}$} & \multirow[t]{2}{*}{$\begin{array}{l}\text { Mol. } \\
\text { wt. }\end{array}$} & \multicolumn{3}{|c|}{ Total inhibitios } & \multicolumn{2}{|c|}{$\begin{array}{l}\text { Inhibition of } \\
\text { respiration } \\
\text { as \% of that } \\
\text { in the control }\end{array}$} \\
\hline & & & $\begin{array}{l}\text { Dilu- } \\
\text { tion }\end{array}$ & $\mathrm{gm} . / \mathrm{l}$ & $\begin{array}{l}\text { Milli- } \\
\text { mol./l. }\end{array}$ & $\underset{\%}{20}$ & $\underset{\%}{40}$ \\
\hline $\begin{array}{l}\text { M. } 1 \\
\text { 'Irga- }\end{array}$ & $\mathrm{C}_{0} \mathrm{H}_{0} \mathrm{~N}$ & 131 & $1 / 8,000$ & 0.125 & $0 \cdot 96$ & 35 & 85 \\
\hline $\begin{array}{l}\text { fen' } \\
W .134\end{array}$ & $\begin{array}{l}\mathrm{C}_{18} \mathrm{H}_{10} \mathrm{O}_{2} \mathrm{~N}_{3} \mathrm{~S} \\
\mathrm{C}_{24} \mathrm{H}_{22} \mathrm{O}_{3} \mathrm{~N}_{4} \mathrm{~S}\end{array}$ & $\begin{array}{l}304 \\
446\end{array}$ & $\begin{array}{l}1 / 10,000 \\
1 / 16,000\end{array}$ & $\begin{array}{l}0 \cdot 100 \\
0 \cdot 063\end{array}$ & $\begin{array}{l}0.33 \\
0.14\end{array}$ & $\begin{array}{r}0 \\
45\end{array}$ & $\begin{array}{l}10 \\
65\end{array}$ \\
\hline
\end{tabular}

It appears from the table that inhibition of growth occurred with a concentration of $1 / 8,000,1 / 10,000$ and $1 / 16,000$ respectively for the substances methylindole, 'Irgafen' and their combination product. The concentration in millimol./litre of the substances is $0.96,0.33$ and 0.14 respectively.

One of the substances coupled, 'Irgafen', has little or no effect on the oxygen consumption of the tubercle bacilli, but methylindole and the finished product diminish it appreciably.

It is thus possible to produce a compound which can interfere with bacterial metabolism by combining two growth-inhibiting substances, of which one is a powerful inhibitor of respiration, and by these means obtain better bacteriostatic power than with either of the substances coupled.

Experiments with many other similarly constructed compounds are in progress. Reports on these will be given later.

Institute of Physical Chemistry, Institute of Hygiene and Bacteriology, University of Uppsala.

Dec. 21

1 Jensen, K. A., et al., Acta Path. et Microbiol. Scand., 20, 133 (1943), Suppl. 54, 277 (1944).

Feldman, W. H., and Hinshaw, H. C., Amer. Rev. Tub., 48, 256 (1943). s Zetterberg, B., unpublished investigations.

- Willstaedt, H., Svensk Kem. Tidskrift, 54, 233 (1942); 56, 267 (1944).

-Willstaedt, H., and Borggård, M., Svensk Kem. Tidskrift, 57, 25 (1945).

- The synthesis of this substance will be described elsewhere by willstaedt. 